\title{
Industrial Production and Capacity Utilization: Annual Revision and 1997 Developments
}

\section{Richard Raddock, of the Board's Division of Research and Statistics, prepared this article. Robert Ritterbeck provided research assistance.}

In December 1997, the Board of Governors of the Federal Reserve System published the results of an annual revision of its measures of industrial production and capacity utilization, which cover the nation's manufacturing, mining, and electric and gas utilities industries. The revision entailed primarily the incorporation of new and more comprehensive source data, the most important of which were annual figures on industry real output in 1995 and survey information on industry utilization rates for the fourth quarters of 1995 and 1996.

The revised measures show stronger growth of production and capacity and lower rates of capacity utilization since 1992 than did earlier estimates (chart 1). The largest revisions to output growth were for 1994 and 1995 and were due mainly to higher figures for manufacturing. The revised production indexes and the new source data on utilization rates implied that manufacturing capacity growth was stronger than previously estimated. Both the earlier and the revised estimates show that capacity utilization reached its most recent high at the beginning of 1995. The revised figures, however, suggest that pressures on industrial capacity since then have been less than previously estimated.

The advance in industrial production over 1997 was almost 6 percent, compared with $41 / 3$ percent on average over the first six years following the March 1991 cyclical trough. ${ }^{1}$ Output in manufacturing increased nearly $6 \frac{1}{2}$ percent during 1997 , with activity in the final quarter especially robust. With the strong growth in manufacturing, the factory operating rate moved to more than 82 percent in late 1997above its 1967-96 average but well below the cyclical peaks in the late 1970s and 1980s.

Note. Other contributors to the revision and this article include the following: Ana Aizcorbe, William Cleveland, Carol Corrado, Christopher Furgiuele, Charles Gilbert, and Michael Mohr.

1. The figures for the fourth quarter of 1997 are subject to further revision in the upcoming monthly G.17 statistical releases.

\section{REVISIONS TO OUTPUT, CAPACITY, AND UTILIZATION}

The average annual rate of growth of industrial production since 1992 is now shown to have been $4 \frac{1}{2}$ percent, $3 / 4$ percentage point higher than previously shown (table 1$){ }^{2}$ The new estimates show

2. Six appendix tables summarize the revised production, capacity, and capacity utilization figures in more detail. The growth rates of production and capacity and the utilization rates are shown with the differences between the revised figures and the earlier estimates. Figures for production growth are shown by market and by industry group; capacity and utilization figures are shown by industry group only.

1. Industrial production, capacity, and utilization, 1977-97

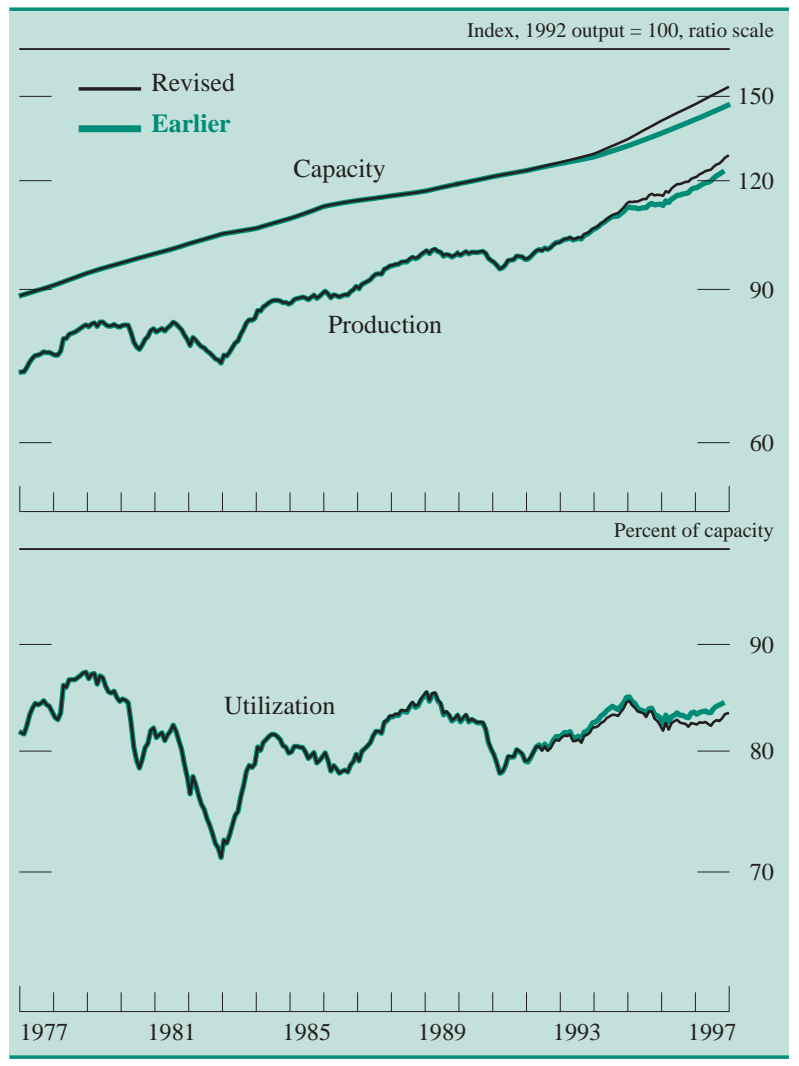

NoTE. In this chart and the charts that follow, revised data for the industrial production indexes are monthly and seasonally adjusted through December 1997. 
1. Annual rates of growth in industrial production, 1992-97

\begin{tabular}{|c|c|c|c|c|c|c|c|c|c|c|}
\hline \multirow{2}{*}{ Item } & \multicolumn{5}{|c|}{$\begin{array}{l}\text { Revised growth rate } \\
\text { (percent) }\end{array}$} & \multicolumn{5}{|c|}{$\begin{array}{l}\text { Difference between growth rates: revised less earlier } \\
\text { (percentage points) }\end{array}$} \\
\hline & 1992-97 & 1994 & 1995 & 1996 & 1997 & 1992-97 & 1994 & 1995 & 1996 & $1997^{1}$ \\
\hline Total index & 4.5 & 6.5 & 3.3 & 4.2 & 5.8 & .7 & .8 & 1.5 & .3 & .2 \\
\hline Manufacturing & 4.9 & 7.6 & 3.3 & 4.7 & 6.4 & .7 & 1.0 & 1.7 & .5 & .2 \\
\hline Durable....... & 7.2 & 9.9 & 6.2 & 6.5 & 9.6 & 1.1 & 1.7 & 2.5 & .8 & .0 \\
\hline $\begin{array}{l}\text { Computers, semiconductors, and } \\
\text { communications equipment } \ldots . . \\
\text { Durable manufacturing excluding }\end{array}$ & 28.1 & 39.2 & 40.6 & 22.8 & 30.4 & 4.9 & 10.7 & 10.7 & 4.4 & 2.5 \\
\hline & 3.1 & 5.3 & .3 & 3.0 & 4.3 & .5 & .4 & 1.0 & .3 & .3 \\
\hline Nondurable $\ldots \ldots \ldots \ldots \ldots \ldots \ldots \ldots$ & 2.4 & 4.9 & -.1 & 2.5 & 2.7 & .5 & .2 & .8 & .2 & .5 \\
\hline Mining & .8 & .9 & -.8 & 1.7 & 2.3 & .0 & -.7 & .5 & -1.7 & -.1 \\
\hline Utilities & 2.3 & -.3 & 6.4 & 1.5 & 2.3 & -.2 & -.2 & -.1 & .0 & .1 \\
\hline
\end{tabular}

industrial output growth to have been $3 / 4$ percentage point higher over 1994 and 11/2 percentage points higher over 1995. The upward revisions to industrial production for 1996 and 1997 averaged 1/4 percentage point.

Stronger gains in the output of informationtechnology products-defined as computers, semiconductors, and communications equipmentaccounted for more than half of the upward revision to industrial production; the largest component of this upward revision was semiconductor output. Output of other types of manufacturing is also now estimated to have grown more rapidly.

Aside from indicating this stronger growth, the updated estimates continue to paint a broad picture of recovery in industrial activity from the 1990 recession through 1994 followed by a slowdown in 1995 and a resumption of relatively robust growth since then. The revised market group indexes suggest that the basic trends underlying the industrial expansion of the 1990s have remained largely unchanged. However, gains in the output of durable industrial materials, including semiconductors, now appear to have contributed even more to the overall growth in industrial production than previously thought.

The annual rate of growth of industrial capacity was revised up $1 \frac{1}{2}$ percentage points for 1995 and 3/4 percentage point for 1996 and 1997 (table 2). The revised annual rate of capacity growth averaged 43/4 percent for total industry over 1995-97 and more than 5 percent for manufacturing for this period. The upward revisions were concentrated in durable manufacturing, especially information-technology industries, in which production rose rapidly because of technological advances. The revised estimates show that capacity growth was faster than previously thought in many other durable and nondurable manufacturing industries (table A.5).

2. Annual rates of growth in industrial capacity, 1992-97

\begin{tabular}{|c|c|c|c|c|c|c|c|c|c|c|}
\hline \multirow{2}{*}{ Item } & \multicolumn{5}{|c|}{$\begin{array}{l}\text { Revised growth rate } \\
\text { (percent) }\end{array}$} & \multicolumn{5}{|c|}{$\begin{array}{l}\text { Difference between growth rates: revised less earlier } \\
\text { (percentage points) }\end{array}$} \\
\hline & $1992-97$ & 1994 & 1995 & 1996 & 1997 & $1992-97$ & 1994 & 1995 & 1996 & 1997 \\
\hline Total index & 3.7 & 3.7 & 4.9 & 4.5 & 4.7 & .8 & .9 & 1.5 & .8 & .8 \\
\hline Manufacturing & 4.1 & 4.1 & 5.5 & 5.1 & 5.3 & .9 & 1.0 & 1.8 & 1.0 & 1.0 \\
\hline $\begin{array}{c}\text { Durable } \ldots \ldots \ldots \ldots \ldots \ldots \ldots \ldots \ldots \ldots \ldots \ldots \ldots \ldots \\
\text { Computers, semiconductors, an }\end{array}$ & 5.8 & 5.9 & 8.3 & 7.5 & 8.0 & 1.3 & 1.8 & 2.8 & 1.3 & 1.4 \\
\hline $\begin{array}{l}\text { communications equipment } \\
\text { Durable manufacturing excluding }\end{array}$ & 26.0 & 27.4 & 37.8 & 30.1 & 30.4 & 4.9 & 7.4 & 11.3 & 3.2 & 3.5 \\
\hline $\begin{array}{l}\text { computers, semiconductors, and } \\
\text { communications equipment } \ldots . . .\end{array}$ & 2.4 & 2.3 & 2.9 & 3.0 & 3.0 & .7 & .5 & 1.1 & 1.0 & 1.2 \\
\hline Nondurable $\ldots \ldots \ldots \ldots . . .$. & 2.2 & 2.0 & 2.3 & 2.4 & 2.2 & .5 & .2 & .7 & .7 & .6 \\
\hline Mining & .3 & 1.0 & -.5 & .2 & .7 & .4 & .4 & .0 & .6 & -.7 \\
\hline Utilities & 1.4 & 1.3 & 2.0 & 1.5 & 1.4 & -.1 & .1 & .1 & -.6 & -.2 \\
\hline
\end{tabular}

NoTE. Growth rates are calculated as the percentage change in the seasonally adjusted index from the fourth quarter of the previous year to the fourth quarter of the year specified in the column heading. The 1992-97 growth rate is

the average annual growth rate from the fourth quarter of 1991 to the fourth quarter of 1997. 
Capacity utilization in manufacturing was revised down $1 / 2$ percentage point for the fourth quarter of 1995 and nearly 1 percentage point for 1996 (table 3). Because the upward revisions to the growth of capacity exceeded those to the growth of production in 1996 and 1997, the downward revisions to manufacturing utilization grew progressively larger and reached nearly $1 \frac{1}{2}$ percentage points in the third quarter of 1997. For the information-technology sector, which operated at relatively low levels from the mid-1980s through the early 1990s, the revision shows the utilization rate still having risen sharply by year-end 1994 and remaining elevated for more than a year after that. Elsewhere in manufacturing, the revisions show utilization rates easing noticeably in 1995.

For mining, the capacity utilization rate in 1996-97 was also revised down-roughly 3 percentage points - with downward revisions to rates for oil and gas extraction, stone and earth minerals, and coal. For electric utilities, the rate of utilization is now estimated to be higher than earlier; electric utility companies have been reluctant to add new generating capability because of the increased uncertainty in a more open market for electric power.

\section{INDUSTRIAL DEVELOPMENTS IN 1997}

Industrial output expanded at a robust pace in 1997. Growth of manufacturing picked up from $43 / 4$ percent in 1996 to nearly $6 \frac{1}{2}$ percent in 1997 , but the expansion was largely accommodated without signs of substantial pressure on productive capability by the acceleration in capacity growth that had started earlier. Within manufacturing, the rate of utilization in primary-processing industries remained relatively high, particularly for primary metals and petroleum products. Among advanced-processing industries, utilization rates were about average overall. Although growth of output and capacity occurred in nearly all the major industry groups, the acceleration and rapid pace of growth were centered in durable manufacturing, a grouping that accounts for nearly one-half the value added in the industrial sector.

\section{Durable Manufacturing}

Output in durable manufacturing increased $91 \frac{1}{2}$ percent during 1997; this growth was led by, but not limited to, the computer, semiconductor, and communications equipment industries. Output of durable manufactures other than computers, semiconductors, and communications equipment also rose solidly, reaching nearly 4 1/2 percent in 1997 (chart 2).

\section{Computers, Semiconductors, and Communications Equipment}

Production of computers, semiconductors, and communications equipment together grew about 30 percent over 1997, compared with about 23 percent over 1996. The acceleration was in the semiconductor industry, for which the rate of output growth

3. Rates of capacity utilization, 1995-97

Percentage of capacity, seasonally adjusted

\begin{tabular}{|c|c|c|c|c|c|c|c|}
\hline \multirow{2}{*}{ Item } & \multicolumn{4}{|c|}{ Revised rate } & \multicolumn{3}{|c|}{$\begin{array}{l}\text { Difference between growth rates: } \\
\text { revised less earlier } \\
\text { (percentage points) }\end{array}$} \\
\hline & $\begin{array}{c}\text { 1988-89 } \\
\text { high }^{1}\end{array}$ & 1995:Q4 & 1996:Q4 & 1997:Q4 & 1995:Q4 & 1996:Q4 & 1997: Q3 \\
\hline Total index & 85.4 & 82.6 & 82.4 & 83.2 & -.5 & -.9 & -1.3 \\
\hline $\begin{array}{l}\text { Manufacturing } . . . . . . \\
\text { Primary processing } \\
\text { Advanced processing }\end{array}$ & $\begin{array}{l}85.7 \\
88.9 \\
84.2\end{array}$ & $\begin{array}{l}81.8 \\
85.8 \\
80.0\end{array}$ & $\begin{array}{l}81.4 \\
85.9 \\
79.4\end{array}$ & $\begin{array}{l}82.2 \\
86.2 \\
80.4\end{array}$ & $\begin{array}{l}-.5 \\
-.4 \\
-.6\end{array}$ & $\begin{array}{r}-.9 \\
-.7 \\
-1.0\end{array}$ & $\begin{array}{l}-1.4 \\
-1.3 \\
-1.5\end{array}$ \\
\hline Durable & 84.6 & 81.2 & 80.4 & 81.6 & -8 & -1.3 & -2.2 \\
\hline $\begin{array}{l}\text { Computers, semiconductors, and } \\
\quad \text { communications equipment } \ldots \ldots \ldots \ldots \ldots \\
\text { Durable manufacturing excluding computers, }\end{array}$ & 81.9 & 86.0 & 81.1 & 81.1 & -1.4 & -.4 & -.9 \\
\hline $\begin{array}{l}\text { semiconductors, and communications } \\
\text { equipment } \ldots \ldots \ldots \ldots \ldots \ldots \ldots \ldots \ldots \ldots\end{array}$ & 86.1 & 81.4 & 81.4 & 82.4 & -.4 & -1.0 & -1.5 \\
\hline Nondurable $\ldots \ldots \ldots \ldots \ldots \ldots \ldots \ldots \ldots \ldots \ldots$ & 87.3 & 82.4 & 82.5 & 82.9 & -.1 & -.5 & -.5 \\
\hline Mining & 88.0 & 87.0 & 88.3 & 89.7 & -1.0 & -3.0 & -2.8 \\
\hline Utilities & 92.6 & 90.0 & 90.0 & 90.8 & -.3 & .2 & .4 \\
\hline
\end{tabular}

1. The "high" column refers to periods in which utilization generally peaked. The monthly highs and lows are specific to each series, and all did not occur in the same month. 


\section{Industrial production, 1992-97}

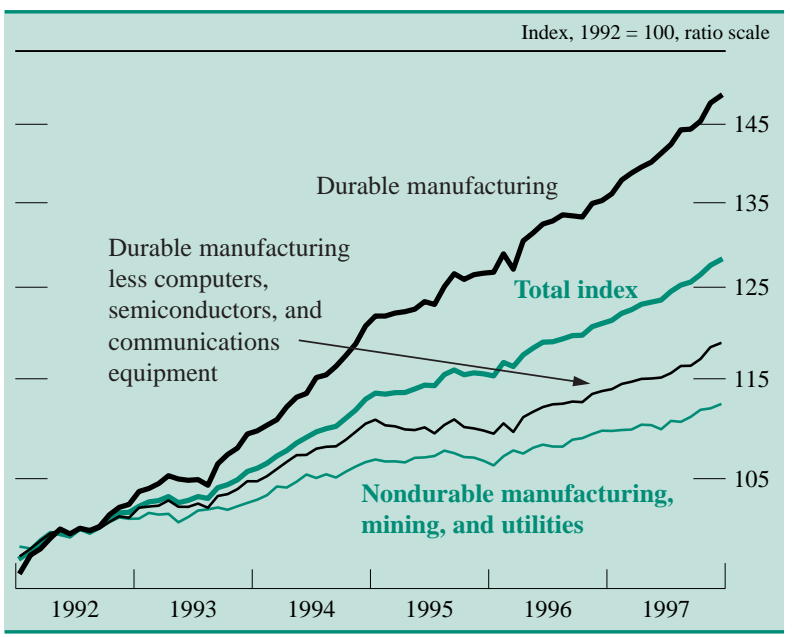

rebounded to 40 percent in 1997 after having slowed over 1996 from the much higher rates of the two preceding years. The 1996 slowdown was related to an unintended stockpiling of semiconductors by producers, distributors, and end-users, who had overestimated the sales of personal computers and related equipment and apparatus for communications.

In 1997, as in earlier years, the rapid growth in the output of information-technology products was accompanied by declining prices. For example, the price of sixteen-bit chips fell from \$11 in May 1997 to less than $\$ 3$ late in the year. Though such declines may be intensified temporarily by excess inventories or capacity, they are sustained by technological progress. Advances in the design of semiconductors

3. Computers, semiconductors, and communications equipment, 1992-97

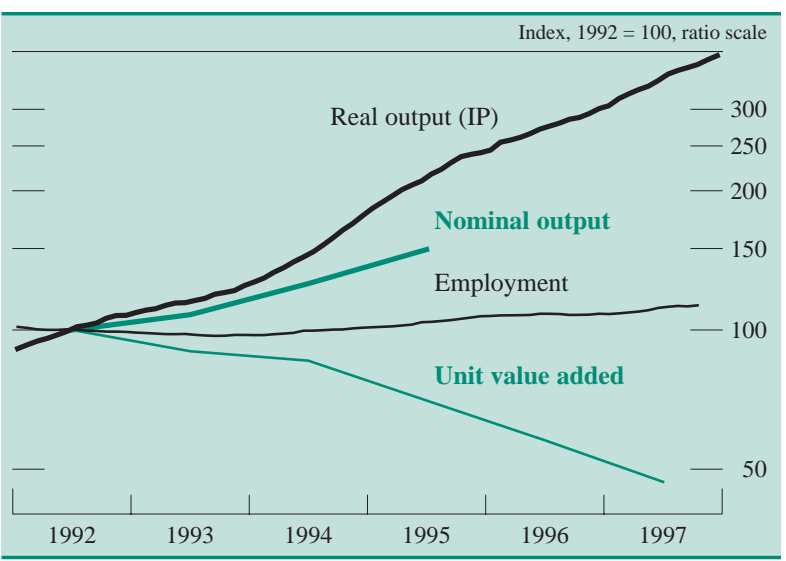

NotE. Real output is the aggregation of the industrial production series for computers, semiconductors, and communications equipment. Nominal output is Census value added plus the cost of materials as reported in the 1992 Census of Manufactures and in the Annual Surveys of Manufactures for 1993 through 1995. Unit value is Census value added divided by the industrial production index for the industries covered. Data for unit value added after 1995 are projections. resulted in improved devices and downstream applications that, for similar prices, have yielded far more services, in terms of millions of instructions per second, memory, disk space, and so forth, than did the earlier devices. The production indexes for computers, semiconductors, and communications equipment have reflected the rapid rise of performance per dollar so that they have risen rapidly relative to both nominal output and employment while the price (unit value added) has plunged (chart 3).

\section{Transportation Equipment}

Over 1997, the output of transportation equipment advanced $11^{1} / 2$ percent. The boom in commercial aircraft and related equipment and parts accounted for the bulk of the increase, but output of motor vehicles grew as well.

Worldwide demand for commercial aircraft rose swiftly, and incoming orders greatly exceeded deliveries in 1997. The Boeing Company's backlog of announced orders for commercial jet airplanes climbed to 1,744 units by the end of the year. Boeing began stepping up production and is working with its suppliers to meet a schedule for delivery of fortythree 7-Series airplanes per month by the spring of 1998 (deliveries of such models averaged eighteen planes per month in 1995 and 1996). Boeing delivered or tendered for delivery 388 airplanes in 1997 and expects to deliver about 550 in 1998. The boom in orders has reflected the growth in world airline traffic and the aging fleet of aircraft. In contrast to the production of commercial aircraft and related parts, the production of military aircraft, which had fallen substantially in 1995, declined a bit further in 1996 and 1997.

The assembly of heavy trucks rebounded in 1997. After hitting a record high in the spring of 1995, the production index for heavy trucks and truck trailers plummeted roughly 30 percent to a trough in the fall of 1996; by November 1997, it had surpassed the 1995 high. Incoming orders greatly exceeded shipments in 1997, and the backlog of unfilled orders for heavy trucks more than doubled over the year. The growth in durable manufacturing production was (and continues to be) a factor in the high level of demand for heavy (class 8) trucks and truck trailers, which are used extensively to transport high-value durable goods such as computers, machine tools, engines, automobiles, and appliances, as well as parts for these goods.

Part of the rise in transportation equipment over 1997 was related to a fourth-quarter jump in assemblies of light vehicles, to an annual rate of about 
12.6 million units, as producers pushed to make up for production lost in the summer because of strikes and new-model-year startup problems. Gains earlier in the year represented, in part, a rebound from the strike-depressed fourth quarter of 1996.

In recent years, sales of light vehicles including imports have, in general, held near 15 million units, and the related production index was only $2 \frac{1}{2}$ percent higher in 1997 than it was in 1994. Light trucks have been gaining market share relative to automobiles: From 1994 to 1997, the production index for light trucks rose about $141 / 2$ percent, whereas the index for automobiles dropped 7 percent. The strength in sales and production of full-size pickup trucks and sport-utility vehicles-especially large, high-priced models-continued in 1997. Sales of light trucks reached about 6.8 million units during the year, an increase of $4 \frac{1}{2}$ percent from a year earlier; sales of automobiles, at 8.3 million units, declined $2 \frac{1}{2}$ percent.

\section{Other Industries}

The production of internal combustion engines and farm, construction, and mining equipment rose about 10 percent in 1997. The pickup in output reflected increased construction of office and other commercial buildings; the high level of homebuilding and government spending on construction of schools, prisons, and highways; and a rise in exports. With the overall strength in durable finished goods and construction activity, the output of primary metals and stone, clay, and glass products rose 5 percent or more.

\section{Major Market Groups}

Among the major market groups, growth has been widespread and substantial in recent years (chart 4). The rapid growth in computers, semiconductors, and communications equipment and the strong performance of motor vehicles and parts, commercial aircraft, and off-highway equipment were key factors in the growth of output of business equipment, durable materials, and consumer durable goods. The production of nondurable consumer goods, held down by declines in apparel and footwear and stagnation in some other categories, continued to grow slowly. Of the major market groups, only the production of defense and space equipment declined.

\section{Consumer Goods}

Strong growth of real income, a rising stock market, and the high level of consumer confidence supported

4. Industrial production, by market group, 1988-97

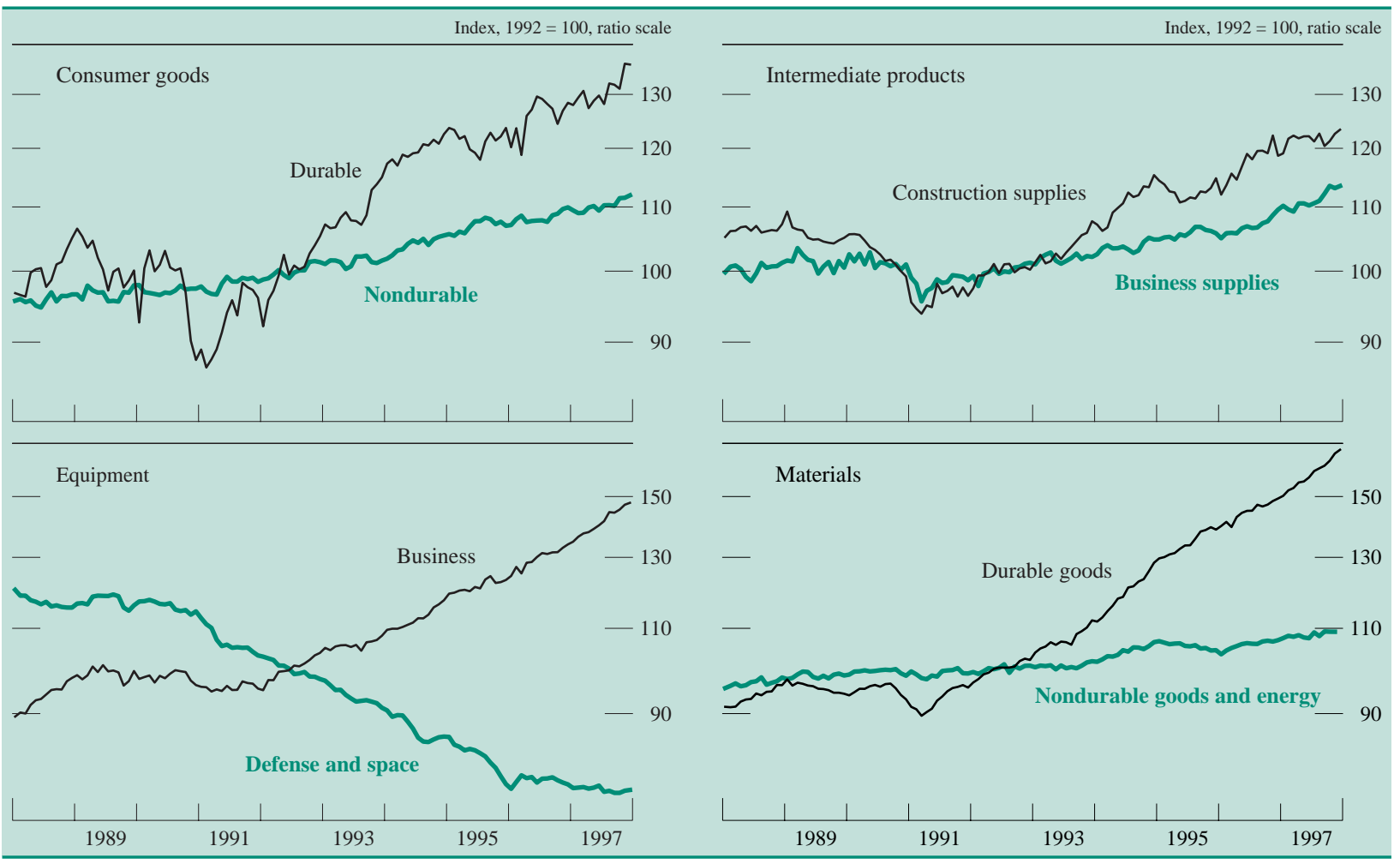


robust increases in the sales and production of consumer goods in 1997. Production of consumer durable goods grew 6 percent over the year, largely because of a 16 percent rise in the output of light trucks and an estimated 40 percent jump in the output of home computers. The production of home appliances remained at a fairly high level. The indexes for other groupings of durable consumer goods, such as carpeting and furniture, generally increased somewhat. The exception was television sets, which showed a sizable drop. The output of nondurable consumer goods, such as foods and tobacco, slowly advanced overall. Gains in chemical and paper products and in automotive gasoline were in the range of 3 percent to $4 \frac{1}{2}$ percent. The production of residential electricity and gas bounced around monthly but was basically flat in 1997, and the output of clothing eased a bit further as domestic production continued to be displaced by imported apparel and footwear.

\section{Equipment}

The output of business equipment, boosted by double-digit growth in the production of computers, trucks, and commercial jets, advanced more than 10 percent during 1997. Output of industrial equipment, which was flat from late 1995 to early 1997 , began to pick up in the spring and strengthened thereafter. The hefty increases in the production of farm equipment and rising backlogs of orders were supported by both domestic demand and demand from abroad, particularly from areas of the former Soviet Union. In contrast, output of railroad equipment, ships, and boats was weak. After years of declines in federal defense spending, the output of defense and space equipment largely flattened out over 1996 and 1997.

The output of mining equipment was spurred by the relative strength in mining activity in 1996 and 1997. In particular, the index for oil and gas well drilling and related oil-field services advanced at an average annual rate of nearly 10 percent over the two years. The higher price of natural gas in 1996 led to increased revenues, which producers spent on capital and exploration in 1997.

\section{Intermediate Products and Materials}

The production of construction supplies continued at a high level, consistent with the solid pace of building activity, and the output of general business supplies grew steadily on balance after some sluggishness in 1995 and early 1996.
With the overall strength in durable finished goods and construction activity, the production index for industrial materials increased more than $7 \frac{1}{2}$ percent during 1997. Among durable goods materials, which grew at a pace of $11 \frac{1}{2}$ percent, output of parts for equipment-especially semiconductors and parts for computers-led the way. The growth in production of consumer durable parts and other durable materials, such as basic metals, was in the 5 percent to 7 percent range. The rate of growth among nondurable goods materials was slower, averaging about 3 percent. Output of paper materials, which had fallen back during 1995 and early 1996, recovered and reached new highs in 1997. Activity in the textile industry picked up in the second half of the year after two years of weakness; however, the level in late 1997 remained below the previous high. The output of chemical materials, such as industrial organic chemicals, flattened out in 1997 after having recovered in 1996. From its level in 1996, the index for energy materials changed little on balance in the first half of 1997, but it rose in the second half of the year with increases in industrial sales of gas and electricity, fossil fuel generation, and gas transmission.

\section{TECHNICAL ASPECTS OF THE ANNUAL REVISION}

The 1997 revision involved mainly the routine incorporation of new and more comprehensive source data, which is done annually. The annual value-added weights used in aggregating the individual indexes were also updated, as were the seasonal factors and productivity relationships. In addition, two individual production series and a handful of capacity and utilization measures were modified between 1987 and 1992. The only substantial change in the industry structure of the production index was the redesign of the series for oil and gas field services, which was carried back to $1987 .{ }^{3}$

\section{Source Data for Production}

The principal contributors to the upward revisions to industrial production were data from the 1995 Annual

3. The modification affected the levels of the aggregate indexes that contain this series before 1987 because the production indexes are chain linked and are expressed as a percentage of output in 1992. All aggregate indexes were subject to very small revisions between 1987 and 1992 because of the aggregation methodology; the annual indexes were essentially unaffected. 
Survey of Manufactures published by the Bureau of the Census and new or revised industry price indexes provided by the Bureau of Economic Analysis. In particular, the revision to the quality-adjusted price index for semiconductors, which shows a larger rate of price decline than estimated earlier, and the introduction of a new quality-adjusted price index for telephone switching and switchboard equipment into the real output benchmark for communications equipment noticeably raised the overall production index. The revision also incorporated more comprehensive 1996 output figures for mining, utilities, and selected manufacturing industries, which were derived from annual industry reports issued by the U.S. Geological Survey, the Energy Information Agency, and the Bureau of the Census.

The physical product data that are used to measure the monthly movements of many individual industrial production indexes were updated to capture data that became available after the closing of the regular four-month reporting window. ${ }^{4}$ Monthly data on production-worker hours or on sales of electric power in kilowatt-hours to industry groups, along with estimates of trends in output per worker-hour or kilowatthour, are used to indicate the monthly change in output for many individual production indexes. In this revision, the Bureau of Labor Statistics benchmark of the employment data for March 1996 was incorporated. More complete reports from the Federal Reserve's Monthly Electric Power Survey were incorporated as well. These monthly kilowatt-hour sales figures were benchmarked to data on the annual use of electric power reported in the Annual Survey of Manufactures through 1995.

Seasonal factors for the electric power series were updated using data through May 1997, and those for the worker hours were based on data through October. Factors for most monthly physical product series were based on data through June. Seasonally adjusted figures for motor vehicle assemblies, which are published in table $2 \mathrm{~A}$ of the regular monthly statistical release, were based on factors estimated with data through October.

\section{Weights}

The industrial production index is an annually weighted Fisher index; capacity utilization is aggregated from component utilization ratios with current

4. Information about the sources of monthly data used to calculate the indexes can be found in "Table 1: Industry structure of industrial production" on the Board's Web site at www.bog.frb.fed.us/releases/ G17/About.htm. capacity proportions; and the contribution of an individual industry to total output or capacity is based on value added by that industry. ${ }^{5}$ In this revision, the annual estimates of industry value added were updated. The Annual Survey of Manufactures as well as revenue and expense data reported by the Department of Energy and the American Gas Association provided information on industry value added in manufacturing and utilities through 1995. The latest value-added data for mining came from the Census of Mineral Industries for 1992.

The weights used in aggregation are expressed as unit value added (value added divided by the related industrial production index). Generally, the unit value-added measures track broad changes in corresponding producer prices. The weights required for aggregation in the most recent period are (1) estimated from available data on producer prices through the most recent year and (2) in light of the persistence of many relative price trends, extrapolated for the following year.

\section{Changes in Series Structure}

The series structure of the index of industrial production, which comprises 264 individual series, remains essentially unchanged. The measurement of oil and gas field services, previously covered by a single series, was split into two series. In addition, the two series on nuclear materials manufacturing were combined into a single series.

The measurement of oil and gas field services was modified to cover the various types of activity in the industry more thoroughly. Previously, a single series based on the count of rotary rigs running, issued by Baker Hughes, was used for all of SIC 138. Now two series cover SIC 138 from 1987 on, one for drilling and exploration (SIC 1381,2) and another for miscellaneous oil and gas field services (SIC 1389).

The new drilling and exploration series, like the previous series for all of SIC 138, is based on the count of rotary rigs running, but the weight given to an offshore rig is much larger than that given to a land rig. The difference-one offshore rig is given the weight of twenty-five land rigs — reflects the much higher rental cost of an offshore rig. For miscellaneous oil and gas field services, the production index is based on active well-servicing units, reported by

5. The aggregation procedures are described in Carol Corrado, Charles Gilbert, and Richard Raddock, "Industrial Production and Capacity Utilization: Historical Revision and Recent Developments," Federal Reserve Bulletin, vol. 83 (February 1997), pp. 67-92. This article is also available on the Board's Web site. 
5. Production in the oil and gas field services industry (SIC 138), 1980-97

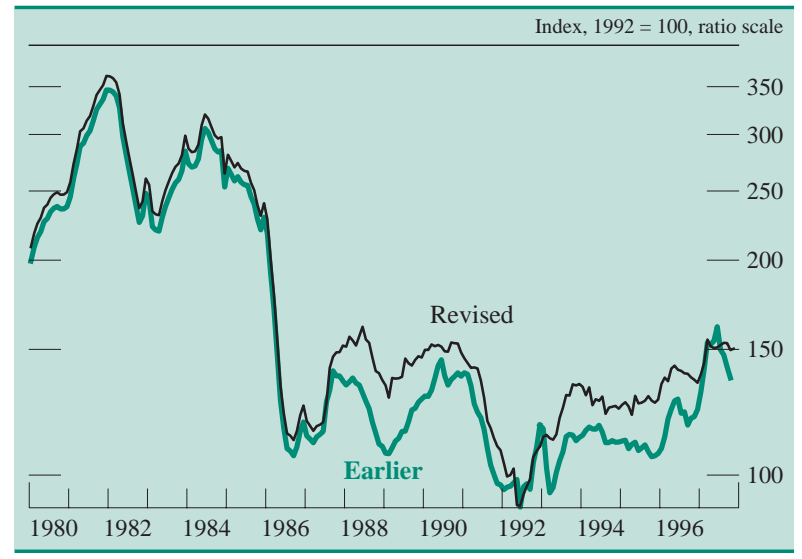

Dresser Oil Tools, plus workover rigs, reported by Baker Hughes. ${ }^{6}$

The revised production index for all of SIC 138 dips more from 1991 to 1992 and rebounds more in 1993 than did the earlier index; the bigger swing reflects the greater weight given to offshore drilling, which was more volatile than onshore drilling during the period (chart 5).

The separate series on defense nuclear materials has been discontinued because of the loss of source data. The single remaining series for nuclear manufacturing (part of SIC 2819) is based on the amount of electricity used in the production of such materials.

\section{Estimates of Capacity and Utilization}

The revisions to capacity and utilization incorporated the revised production indexes, the preliminary results of the 1996 Survey of Plant Capacity conducted by the Bureau of the Census, updated measures of 1996 and 1997 capacity in physical units for selected industries, and revised estimates of industry capital input.

The first step in constructing the individual capacity indexes is calculating preliminary, implied end-of-

6. Well-servicing units are truck-mounted equipment generally used for servicing a well after it is drilled. Such units are used for well completions, maintenance, repairs, well plugging, and abandonments. They include workover rigs, for which the daily costs of operation are generally higher than those of other types of units. The Baker Hughes workover rig count includes only equipment for wells that are 1,500 feet or more in depth and for which tubing is out of the well bore. The addition of this workover rig count to the number of active wellservicing units approximately doubled the weight given to workover rigs to reflect their higher daily cost. the-year indexes of capacity by dividing a production index by a utilization rate obtained from a survey for that end-of-year period. These ratios are expressed, like the indexes of industrial production, as percentages of production in 1992, and they indicate the general level and trend of the capacity estimates. ${ }^{7}$

The Census Bureau's Survey of Plant Capacity is the source of utilization rates used to derive the initial estimates of capacity for most manufacturing industries. The 1996 survey covered about 70 percent more plants than earlier surveys (approximately 17,000 compared with 10,000), and the preliminary results available for the 1997 annual revision were much more refined and detailed than those used in earlier annual revisions. Because of the marked expansion of the reporting panel and the greater availability of refined industry detail, results from a panel of respondents who had previously participated in the survey were reviewed to maintain the consistency of the Federal Reserve estimates over time. The Census survey results suggested that factory operating rates were lower in recent years than previously estimated by the Federal Reserve. Dividing the industrial production indexes, which were generally revised upward, by the lower-than-expected Census utilization rates implied noticeably higher capacity.

The second step in constructing individual capacity indexes is using measures of physical capacity or of capital input to estimate and extrapolate the annual movements of the final capacity indexes. For most manufacturing industries, measures of physical capacity are lacking; in these cases, the annual growth in the capacity estimates is derived from econometric models that relate the increase in the figures on implied capacity to the growth of an indus-

7. Each implied capacity index number is an estimate of a sustainable maximum level of output expressed as a percentage of actual output in 1992. Thus, if in the fourth quarter of 1992 the production index is 100 and a related utilization rate from a survey is 80 percent, then the implied capacity index is $100 / .8=125$.

The capacity indexes capture the concept of sustainable practical capacity, which is defined as the greatest level of output that a plant can maintain within the framework of a realistic work schedule after taking account of normal downtime and assuming sufficient availability of inputs to operate the machinery and equipment in place. Both the questions asked in the broad Census survey and the narrower surveys of selected industries are generally consistent with this definition of capacity. The concept itself generally conforms to that of a full-input point on a production function, with the qualification that capacity represents a realistically sustainable maximum rather than some higher, unsustainable short-term maximum. See Carol Corrado and Joe Mattey, "Capacity Utilization," Journal of Economic Perspectives, vol. 11 (Winter 1997), pp. 151-67.

In the absence of utilization rate information for an industry, which is the case for a few series in mining, trends through peaks in production are used to estimate capacity output for that industry. 


\section{Data Availability}

Files containing the revised data and the text and tables from the supplement to the G.17 release, "Industrial Production and Capacity Utilization: Historical Revision," are available on the Board's World Wide Web site at http://www.bog.frb.fed.us. Files are also available through the Economic Bulletin Board of the Department of Commerce; for information, call (202) 482-1986. Diskettes containing either historical data (through 1985) or more recent data (1986 to those most recently published in the G.17 release) are available from Publications Services, Board of Governors of the Federal Reserve System, Washington, DC 20551, or phone (202) 452-3245.

try's capital input and a function that captures the growth of an industry's productivity of capital.

For this revision, the capital input measures, which reflect estimates of the service flows derived from the net stocks of productive tangible assets, incorporate updated BEA estimates of new business investment and deflators by asset type for 1993-97. (Figures on industry investment through 1995 were incorporated for the preliminary 1997 capacity estimate issued in
March 1997.) The capital input measures were also revised historically to incorporate revised estimates of manufacturers' investment in computers for 1968-97 and revised estimates of manufacturers' investment in the components of structures for 197897. The new estimates of computer investment were developed from sample data collected in conjunction with the Census of Manufactures for 1977, 1982, 1987, and 1992, and the new estimates of components of structures were based on data collected by the Census Bureau in its 1994 Annual Capital Expenditures Survey.

Overall, the average annual growth rate of capital input in 1995-97 was 0.1 percentage point lower than previously estimated. Thus, the revised capital input estimates, in conjunction with the new survey data on utilization rates and the revised production indexes, suggest that a higher rate of growth of aggregate manufacturing capital productivity more than accounts for the upward revision to the capacity growth rates. However, the average annual growth rate of capital input in 1995-97 was noticeably higher for furniture, plastics products, fabricated metal products, computer and office equipment, communications equipment, and aircraft and parts. 


\section{APPENDIX A: SUMMARY TABLES BASED ON THE G.17 RELEASE, JANUARY 16, 1998}

A.1. Revised data for industrial production, capacity, and utilization for total industry, 1987-97

Seasonally adjusted data except as noted

\begin{tabular}{|c|c|c|c|c|c|c|c|c|c|c|c|c|c|c|c|c|c|}
\hline \multirow{2}{*}{ Year } & \multirow{2}{*}{ Jan. } & \multirow{2}{*}{ Feb. } & \multirow{2}{*}{ Mar. } & \multirow{2}{*}{ Apr. } & \multirow{2}{*}{ May } & \multirow{2}{*}{ June } & \multirow{2}{*}{ July } & \multirow{2}{*}{ Aug. } & \multirow{2}{*}{ Sept. } & \multirow{2}{*}{ Oct. } & \multirow{2}{*}{ Nov. } & \multirow{2}{*}{ Dec. } & \multicolumn{4}{|c|}{ Quarter } & \multirow{2}{*}{$\begin{array}{l}\text { Annua } \\
\text { avg. }{ }^{1}\end{array}$} \\
\hline & & & & & & & & & & & & & 1 & 2 & 3 & 4 & \\
\hline & & & & & & & Industr & al produ & tion (pe & centage & hange) & & & & & & \\
\hline 1987 & -.6 & 1.2 & .4 & .4 & .4 & .9 & 6 & .1 & -.1 & 1.4 & .3 & .6 & 4.2 & 6.7 & 5.6 & 7.1 & 4.6 \\
\hline 1988 & .1 & .3 & .0 & 6 & .1 & .1 & .7 & .5 & -.4 & .3 & .8 & .5 & 3.2 & 3.1 & 3.9 & 3.6 & 4.5 \\
\hline 1989 & .6 & -.8 & .9 & .2 & -.6 & -.2 & -1.0 & .4 & -.2 & -.5 & .4 & .5 & 3.8 & .5 & -4.4 & -.1 & 1.8 \\
\hline 1990 & -.5 & .5 & .5 & -.6 & .4 & .0 & .0 & .2 & .1 & -.6 & -1.3 & -.6 & 2.0 & 6 & 1.0 & -5.8 & -.2 \\
\hline 1991 & -.5 & -.8 & -.9 & .3 & .8 & 1.2 & .1 & .1 & 1.0 & -.1 & -.1 & -.6 & -8.3 & 1.5 & 6.2 & 1.1 & -2.0 \\
\hline 1992 & .2 & .6 & .7 & .8 & .2 & -.3 & .7 & -.3 & .5 & .8 & .5 & .1 & 1.4 & 6.2 & 1.9 & 5.5 & 3.1 \\
\hline 1993 & .5 & .4 & .1 & .4 & -.6 & .2 & .4 & -.2 & 1.0 & .3 & .4 & .8 & 4.4 & 1.1 & 2.1 & 5.8 & 3.6 \\
\hline 1994 & .3 & .5 & .7 & .5 & .7 & .5 & .5 & .3 & .2 & .7 & .8 & 1.0 & 6.0 & 7.1 & 5.5 & 7.5 & 5.4 \\
\hline 1995 & .6 & -.1 & .1 & .0 & .3 & .3 & .0 & 1.0 & .4 & -.4 & .2 & -.1 & 5.9 & 1.6 & 4.5 & 1.1 & 4.9 \\
\hline 1996 & -.2 & 1.2 & -.4 & 1.1 & 6 & .5 & .0 & .3 & .3 & .0 & .8 & .3 & 2.0 & 7.5 & 3.6 & 3.8 & 3.5 \\
\hline 1997 & .3 & .6 & .3 & .5 & .2 & .2 & .8 & .6 & .3 & .5 & .8 & .5 & 5.2 & 4.6 & 6.0 & 7.4 & 5.0 \\
\hline & & & & & & & & ndustrial & product & on (inde & & & & & & & \\
\hline 1987 & 90.2 & 91.2 & 91.6 & 92.0 & 92.4 & 93.2 & 93.7 & 93.8 & 93.7 & 95.0 & 95.3 & 95.9 & 91.0 & 92.5 & 93.8 & 95.4 & 93.2 \\
\hline 1988 & 95.9 & 96.2 & 96.3 & 96.8 & 96.9 & 97.0 & 97.6 & 98.1 & 97.8 & 98.0 & 98.8 & 99.3 & 96.1 & 96.9 & 97.8 & 98.7 & 97.4 \\
\hline 1989 & 99.8 & 99.0 & 100.0 & 100.2 & 99.6 & 99.4 & 98.4 & 98.8 & 98.6 & 98.2 & 98.6 & 99.0 & 99.6 & 99.7 & 98.6 & 98.6 & 99.1 \\
\hline 1990 & 98.6 & 99.1 & 99.6 & 99.0 & 99.4 & 99.3 & 99.3 & 99.5 & 99.6 & 99.1 & 97.7 & 97.2 & 99.1 & 99.2 & 99.5 & 98.0 & 98.9 \\
\hline 1991 & 96.7 & 95.9 & 95.0 & 95.4 & 96.1 & 97.2 & 97.3 & 97.4 & 98.4 & 98.3 & 98.1 & 97.5 & 95.9 & 96.2 & 97.7 & 98.0 & 97.0 \\
\hline 1992 & 97.7 & 98.3 & 99.0 & 99.8 & 100.0 & 99.7 & 100.3 & 100.0 & 100.5 & 101.2 & 101.8 & 101.8 & 98.3 & 99.8 & 100.3 & 101.6 & 100.0 \\
\hline 1993 & 102.4 & 102.8 & 102.9 & 103.3 & 102.7 & 102.9 & 103.3 & 103.1 & 104.1 & 104.4 & 104.9 & 105.7 & 102.7 & 103.0 & 103.5 & 105.0 & 103.6 \\
\hline 1994 & 106.0 & 106.5 & 107.2 & 107.7 & 108.5 & 109.0 & 109.6 & 109.9 & 110.1 & 110.9 & 111.8 & 112.9 & 106.6 & 108.4 & 109.9 & 111.9 & 109.2 \\
\hline 1995 & 113.5 & 113.4 & 113.6 & 113.6 & 113.9 & 114.3 & 114.3 & 115.4 & 115.9 & 115.4 & 115.6 & 115.5 & 113.5 & 113.9 & 115.2 & 115.5 & 114.5 \\
\hline 1996 & 115.3 & 116.7 & 116.3 & 117.5 & 118.3 & 118.9 & 118.9 & 119.3 & 119.6 & 119.7 & 120.6 & 120.9 & 116.1 & 118.2 & 119.3 & 120.4 & 118.5 \\
\hline 1997 & 121.3 & 122.1 & 122.5 & 123.1 & 123.3 & 123.5 & 124.5 & 125.2 & 125.6 & 126.5 & 127.5 & 128.1 & 121.9 & 123.3 & 125.1 & 127.4 & 124.5 \\
\hline & & & & & & & & Cap & acity (in & lex) & & & & & & & \\
\hline 1987 & 114.0 & 114.1 & 114.2 & 114.3 & 114.4 & 114.5 & 114.6 & 114.7 & 114.9 & 115.0 & 115.1 & 115.2 & 114.1 & 114.4 & 114.7 & 115.1 & 114.6 \\
\hline 1988 & 115.3 & 115.5 & 115.6 & 115.7 & 115.8 & 115.9 & 116.0 & 116.2 & 116.3 & 116.4 & 116.5 & 116.7 & 115.5 & 115.8 & 116.2 & 116.5 & 116.0 \\
\hline 1989 & 116.8 & 117.0 & 117.2 & 117.4 & 117.6 & 117.8 & 118.0 & 118.2 & 118.4 & 118.6 & 118.8 & 119.0 & 117.0 & 117.6 & 118.2 & 118.8 & 117.9 \\
\hline 1990 & 119.2 & 119.3 & 119.5 & 119.7 & 119.9 & 120.1 & 120.2 & 120.4 & 120.6 & 120.8 & 121.0 & 121.2 & 119.3 & 119.9 & 120.4 & 121.0 & 120.2 \\
\hline 1991 & 121.4 & 121.6 & 121.7 & 121.9 & 122.1 & 122.2 & 122.4 & 122.6 & 122.7 & 122.9 & 123.0 & 123.2 & 121.6 & 122.1 & 122.6 & 123.0 & 122.3 \\
\hline 1992 & 123.4 & 123.6 & 123.8 & 124.1 & 124.3 & 124.5 & 124.8 & 125.0 & 125.2 & 125.4 & 125.6 & 125.8 & 123.6 & 124.3 & 125.0 & 125.6 & 124.6 \\
\hline 1993 & 126.1 & 126.3 & 126.5 & 126.8 & 127.0 & 127.2 & 127.5 & 127.7 & 128.0 & 128.2 & 128.5 & 128.7 & 126.3 & 127.0 & 127.7 & 128.5 & 127.4 \\
\hline 1994 & 129.1 & 129.5 & 129.9 & 130.3 & 130.7 & 131.2 & 131.6 & 132.0 & 132.4 & 132.8 & 133.3 & 133.7 & 129.5 & 130.7 & 132.0 & 133.3 & 131.4 \\
\hline 1995 & 134.2 & 134.8 & 135.3 & 135.9 & 136.5 & 137.1 & 137.6 & 138.1 & 138.7 & 139.2 & 139.8 & 140.4 & 134.8 & 136.5 & 138.1 & 139.8 & 137.3 \\
\hline 1996 & 140.9 & 141.4 & 142.0 & 142.5 & 143.0 & 143.6 & 144.1 & 144.6 & 145.1 & 145.6 & 146.1 & 146.7 & 141.4 & 143.0 & 144.6 & 146.1 & 143.8 \\
\hline 1997 & 147.2 & 147.8 & 148.4 & 149.0 & 149.6 & 150.2 & 150.7 & 151.3 & 151.9 & 152.4 & 153.0 & 153.6 & 147.8 & 149.6 & 151.3 & 153.0 & 150.4 \\
\hline & & & & & & & & Utilizati & in (revel & percent & & & & & & & \\
\hline 1987 & 79.1 & 80.0 & 80.2 & 80.5 & 80.7 & 81.4 & 81.8 & 81.8 & 8 & 82.6 & 82.8 & 83.2 & 79.8 & 80.8 & 81.7 & 82.9 & 81.3 \\
\hline 1988 & 83.2 & 83.4 & 83.3 & 83.7 & 83.7 & 83.6 & 84.1 & 84.5 & 84.1 & 84.2 & 84.8 & 85. & 83.3 & 83.7 & 84.2 & 84.7 & 84.0 \\
\hline 1989 & 85.4 & 84.6 & 85.3 & 85.3 & 84.7 & 84.4 & 83.4 & 83.6 & 83.3 & 82.8 & 83.0 & 83.2 & 85.1 & 84.8 & 83.4 & 83.0 & 84.1 \\
\hline 1990 & 82.7 & 83.0 & 83.3 & 82.7 & 82.9 & 82.7 & 82.6 & 82.6 & 82.6 & 82.0 & 80.8 & 80.2 & 83.0 & 82.8 & 82.6 & 81.0 & 82.3 \\
\hline 1991 & 79.6 & 78.9 & 78.1 & 78.2 & 78.7 & 79.6 & 79.5 & 79.5 & 80.2 & 80.0 & 79.8 & 79.2 & 78.9 & 78.8 & 79.7 & 79.6 & 79.3 \\
\hline 1992 & 79.2 & 79.5 & 79.9 & 80.4 & 80.4 & 80.0 & 80.4 & 80.0 & 80.2 & 80.7 & 81.0 & 80.9 & 79.5 & 80.3 & 80.2 & 80.9 & 80.2 \\
\hline 1993 & 81.2 & 81.4 & 81.3 & 81.5 & 80.9 & 80.9 & 81.0 & 80.7 & 81.4 & 81.4 & 81.6 & 82.1 & 81.3 & 81.1 & 81.0 & 81.7 & 81.3 \\
\hline 1994 & 82.1 & 82.2 & 82.5 & 82.7 & 83.0 & 83.1 & 83.3 & 83.3 & 83.2 & 83.5 & 83.9 & 84.4 & 82.3 & 82.9 & 83.2 & 83.9 & 83.1 \\
\hline 1995 & 84.6 & 84.2 & 83.9 & 83.6 & 83.5 & 83.4 & 83.1 & 83.6 & 83.6 & 82.9 & 82.7 & 82.3 & 84.2 & 83.5 & 83.4 & 82.6 & 83.4 \\
\hline 1996 & 81.8 & 82.5 & 81.9 & 82.5 & 82.7 & 82.8 & 82.6 & 82.5 & 82.4 & 82.2 & 82.5 & 82.5 & 82.1 & 82.7 & 82.5 & 82.4 & 82.4 \\
\hline 1997 & 82.4 & 82.6 & 82.5 & 82.6 & 82.4 & 82.3 & 82.6 & 82.8 & 82.7 & 83.0 & 83.3 & 83.4 & 82.5 & 82.4 & 82.7 & 83.2 & 82.7 \\
\hline
\end{tabular}

NoTE. Monthly figures show the percentage change from the previous month; quarterly figures show the change from the previous quarter at a compound

1. Annual averages of industrial production are calculated from indexes that annual rate of growth. Production and capacity indexes are expressed as percentare not seasonally adjusted. ages of output in 1992. 
A.2. Revised data for industrial production, capacity, and utilization for manufacturing industries, 1987-97 Seasonally adjusted data except as noted

\begin{tabular}{|c|c|c|c|c|c|c|c|c|c|c|c|c|c|c|c|c|c|}
\hline \multirow{2}{*}{ Year } & \multirow{2}{*}{ Jan. } & \multirow{2}{*}{ Feb. } & \multirow{2}{*}{ Mar. } & \multirow{2}{*}{ Apr. } & \multirow{2}{*}{ May } & \multirow{2}{*}{ June } & \multirow{2}{*}{ July } & \multirow{2}{*}{ Aug. } & \multirow{2}{*}{ Sept. } & \multirow{2}{*}{ Oct. } & \multirow{2}{*}{ Nov. } & \multirow{2}{*}{ Dec. } & \multicolumn{4}{|c|}{ Quarter } & \multirow{2}{*}{$\begin{array}{l}\text { Annua } \\
\text { avg. }\end{array}$} \\
\hline & & & & & & & & & & & & & 1 & 2 & 3 & 4 & \\
\hline & & & & & & & Industr & al produ & tion (pe & centage & hange) & & & & & & \\
\hline 1987 & -.8 & 1.6 & .2 & .5 & .3 & 1.0 & .7 & -.2 & .1 & 1.3 & .5 & .6 & 5.0 & 7.0 & 5.5 & 7.6 & 5.3 \\
\hline 1988 & -.2 & .4 & -.1 & 1.0 & -.1 & .0 & .7 & .3 & .2 & .2 & .9 & .6 & 2.3 & 4.1 & 3.7 & 5.2 & 4.7 \\
\hline 1989 & .9 & -1.2 & .8 & .1 & -.7 & .0 & -1.1 & .3 & -.3 & -.6 & .4 & .1 & 4.3 & -.7 & -4.5 & -1.4 & 1.9 \\
\hline 1990 & -.2 & .9 & .3 & -.8 & .4 & -.1 & .0 & .3 & -.1 & -.6 & -1.3 & -.6 & 2.9 & -.1 & .8 & -6.3 & -.5 \\
\hline 1991 & -.9 & -.7 & -1.1 & .3 & .7 & 1.4 & .2 & .2 & 1.1 & -.1 & -.2 & -.5 & -9.7 & 1.2 & 7.8 & 1.7 & -2.4 \\
\hline 1992 & 4 & .7 & .8 & .7 & .4 & -.1 & .6 & -.3 & .4 & .7 & .6 & -.1 & 2.8 & 7.0 & 2.4 & 5.0 & 4.0 \\
\hline 1993 & 1.0 & .2 & .1 & .6 & -.5 & .0 & .4 & -.3 & 1.1 & .2 & .5 & .9 & 5.0 & 1.6 & 1.6 & 6.2 & 3.8 \\
\hline 1994 & .1 & .6 & .8 & .8 & .8 & .2 & .7 & .4 & .3 & .9 & .9 & 1.0 & 6.3 & 8.8 & 6.2 & 9.0 & 6.0 \\
\hline 1995 & .6 & -.2 & .2 & .0 & .2 & .4 & -.2 & .9 & .7 & -.4 & .0 & -.1 & 6.4 & 1.4 & 3.9 & 1.5 & 5.4 \\
\hline 1996 & -.1 & 1.2 & -.6 & 1.4 & .6 & .6 & .4 & .2 & .3 & .0 & .8 & .5 & 1.5 & 8.1 & 4.9 & 4.2 & 3.6 \\
\hline 1997 & .3 & .7 & .4 & .4 & .2 & .3 & .6 & .7 & .1 & .7 & 1.2 & .5 & 6.2 & 4.9 & 6.1 & 8.3 & 5.7 \\
\hline & & & & & & & & ndustrial & product & n (inde & & & & & & & \\
\hline 1987 & 89.6 & 91.0 & 91.2 & 91.6 & 91.9 & 92.8 & 93.4 & 93.3 & 93.4 & 94.6 & 95.1 & 95.6 & 90.6 & 92.1 & 93.4 & 95.1 & 92.8 \\
\hline 1988 & 95.4 & 95.8 & 95.7 & 96.7 & 96.6 & 96.6 & 97.3 & 97.5 & 97.7 & 97.9 & 98.9 & 99.4 & 95.6 & 96.6 & 97.5 & 98.7 & 97.1 \\
\hline 1989 & 100.3 & 99.1 & 99.9 & 100.0 & 99.4 & 99.4 & 98.3 & 98.7 & 98.4 & 97.8 & 98.2 & 98.3 & 99.8 & 99.6 & 98.5 & 98.1 & 99.0 \\
\hline 1990 & 98.1 & 99.0 & 99.3 & 98.6 & 99.0 & 98.9 & 98.8 & 99.1 & 99.0 & 98.4 & 97.2 & 96.6 & 98.8 & 98.8 & 99.0 & 97.4 & 98.5 \\
\hline 1991 & 95.8 & 95.1 & 94.1 & 94.4 & 95.0 & 96.3 & 96.6 & 96.8 & 97.8 & 97.8 & 97.6 & 97.1 & 95.0 & 95.2 & 97.0 & 97.5 & 96.2 \\
\hline 1992 & 97.4 & 98.1 & 98.9 & 99.6 & 100.0 & 99.8 & 100.5 & 100.2 & 100.6 & 101.3 & 101.9 & 101.7 & 98.1 & 99.8 & 100.4 & 101.6 & 100.0 \\
\hline 1993 & 102.7 & 102.9 & 103.0 & 103.6 & 103.1 & 103.1 & 103.5 & 103.2 & 104.4 & 104.6 & 105.2 & 106.0 & 102.9 & 103.3 & 103.7 & 105.3 & 103.8 \\
\hline 1994 & 106.2 & 106.8 & 107.7 & 108.5 & 109.4 & 109.6 & 110.4 & 110.9 & 111.2 & 112.2 & 113.2 & 114.3 & 106.9 & 109.2 & 110.8 & 113.2 & 110.0 \\
\hline 1995 & 115.1 & 114.9 & 115.1 & 115.1 & 115.3 & 115.8 & 115.5 & 116.6 & 117.5 & 117.0 & 117.0 & 116.9 & 115.0 & 115.4 & 116.5 & 116.9 & 116.0 \\
\hline 1996 & 116.7 & 118.1 & 117.4 & 119.0 & 119.7 & 120.4 & 120.9 & 121.1 & 121.5 & 121.5 & 122.5 & 123.1 & 117.4 & 119.7 & 121.1 & 122.4 & 120.2 \\
\hline 1997 & 123.5 & 124.4 & 124.9 & 125.4 & 125.7 & 126.1 & 126.9 & 127.9 & 128.0 & 128.9 & 130.5 & 131.1 & 124.2 & 125.7 & 127.6 & 130.2 & 127.0 \\
\hline & & & & & & & & Cap & acity (in & lex) & & & & & & & \\
\hline 1987 & 113.2 & 113.4 & 113.6 & 113.8 & 113.9 & 114.1 & 114.2 & 114.4 & 114.6 & 114.7 & 114.9 & 115.0 & 113.4 & 113.9 & 114.4 & 114.9 & 114.1 \\
\hline 1988 & 115.2 & 115.3 & 115.4 & 115.6 & 115.7 & 115.8 & 116.0 & 116.1 & 116.3 & 116.5 & 116.6 & 116.8 & 115.3 & 115.7 & 116.1 & 116.6 & 115.9 \\
\hline 1989 & 117.0 & 117.3 & 117.5 & 117.8 & 118.0 & 118.3 & 118.5 & 118.7 & 119.0 & 119.2 & 119.5 & 119.7 & 117.3 & 118.0 & 118.7 & 119.5 & 118.4 \\
\hline 1990 & 119.9 & 120.1 & 120.3 & 120.5 & 120.7 & 120.9 & 121.1 & 121.3 & 121.5 & 121.7 & 122.0 & 122.2 & 120.1 & 120.7 & 121.3 & 122.0 & 121.0 \\
\hline 1991 & 122.4 & 122.6 & 122.8 & 123.0 & 123.1 & 123.3 & 123.5 & 123.7 & 123.8 & 124.0 & 124.2 & 124.3 & 122.6 & 123.1 & 123.7 & 124.2 & 123.4 \\
\hline 1992 & 124.6 & 124.8 & 125.1 & 125.3 & 125.6 & 125.8 & 126.1 & 126.3 & 126.6 & 126.8 & 127.0 & 127.3 & 124.8 & 125.6 & 126.3 & 127.0 & 125.9 \\
\hline 1993 & 127.6 & 127.8 & 128.1 & 128.3 & 128.6 & 128.9 & 129.1 & 129.4 & 129.7 & 129.9 & 130.2 & 130.5 & 127.8 & 128.6 & 129.4 & 130.2 & 129.0 \\
\hline 1994 & 130.9 & 131.3 & 131.8 & 132.2 & 132.7 & 133.2 & 133.6 & 134.1 & 134.6 & 135.1 & 135.5 & 136.0 & 131.3 & 132.7 & 134.1 & 135.5 & 133.4 \\
\hline 1995 & 136.6 & 137.2 & 137.8 & 138.5 & 139.1 & 139.8 & 140.4 & 141.1 & 141.7 & 142.4 & 143.0 & 143.7 & 137.2 & 139.2 & 141.1 & 143.0 & 140.1 \\
\hline 1996 & 144.3 & 144.9 & 145.6 & 146.2 & 146.8 & 147.4 & 148.0 & 148.6 & 149.2 & 149.8 & 150.4 & 151.0 & 144.9 & 146.8 & 148.6 & 150.4 & 147.7 \\
\hline 1997 & 151.6 & 152.3 & 152.9 & 153.6 & 154.3 & 155.0 & 155.7 & 156.3 & 157.0 & 157.6 & 158.3 & 159.0 & 152.3 & 154.3 & 156.3 & 158.3 & 155.3 \\
\hline & & & & & & & & Utilizati & n (level & percent & & & & & & & \\
\hline 1987 & 79.1 & 80.2 & 80.3 & 80.6 & 80.7 & 81.4 & 81.8 & 81.5 & 81.5 & 82.5 & 82.8 & 83.1 & 79.9 & 80.9 & 81.6 & 82.8 & 81.3 \\
\hline 1988 & 82.9 & 83.1 & 82.9 & 83.7 & 83.5 & 83.4 & 83.8 & 84.0 & 84.0 & 84.1 & 84.8 & 85.1 & 83.0 & 83.5 & 83.9 & 84.7 & 83.8 \\
\hline 1989 & 85.7 & 84.5 & 85.0 & 85.0 & 84.2 & 84.1 & 83.0 & 83.1 & 82.7 & 82.1 & 82.2 & 82.1 & 85.1 & 84.4 & 82.9 & 82.1 & 83.6 \\
\hline 1990 & 81.8 & 82.5 & 82.6 & 81.8 & 82.0 & 81.8 & 81.6 & 81.7 & 81.5 & 80.9 & 79.7 & 79.0 & 82.3 & 81.9 & 81.6 & 79.9 & 81.4 \\
\hline 1991 & 78.2 & 77.5 & 76.6 & 76.8 & 77.1 & 78.1 & 78.2 & 78.2 & 79.0 & 78.9 & 78.6 & 78.1 & 77.5 & 77.3 & 78.5 & 78.5 & 77.9 \\
\hline 1992 & 78.2 & 78.6 & 79.1 & 79.5 & 79.6 & 79.4 & 79.7 & 79.3 & 79.5 & 79.9 & 80.2 & 79.9 & 78.6 & 79.5 & 79.5 & 80.0 & 79.4 \\
\hline 1993 & 80.5 & 80.5 & 80.4 & 80.7 & 80.2 & 80.0 & 80.2 & 79.8 & 80.5 & 80.5 & 80.8 & 81.3 & 80.5 & 80.3 & 80.1 & 80.8 & 80.5 \\
\hline 1994 & 81.1 & 81.3 & 81.7 & 82.1 & 82.4 & 82.3 & 82.6 & 82.7 & 82.6 & 83.0 & 83.5 & 84.1 & 81.4 & 82.3 & 82.6 & 83.5 & 82.5 \\
\hline 1995 & 84.3 & 83.7 & 83.5 & 83.1 & 82.9 & 82.8 & 82.3 & 82.6 & 82.9 & 82.2 & 81.8 & 81.3 & 83.8 & 82.9 & 82.6 & 81.8 & 82.8 \\
\hline 1996 & 80.8 & 81.5 & 80.6 & 81.4 & 81.6 & 81.7 & 81.7 & 81.5 & 81.4 & 81.1 & 81.5 & 81.5 & 81.0 & 81.6 & 81.5 & 81.4 & 81.4 \\
\hline 1997 & 81.4 & 81.7 & 81.6 & 81.6 & 81.4 & 81.3 & 81.5 & 81.8 & 81.6 & 81.8 & 82.4 & 82.5 & 81.6 & 81.5 & 81.6 & 82.2 & 81.7 \\
\hline
\end{tabular}

Note. See notes to table A.1. 
A.3. Rates of growth in industrial production, by major market group, 1993-97

\begin{tabular}{|c|c|c|c|c|c|c|c|c|c|c|}
\hline \multirow[t]{2}{*}{ Market group } & \multicolumn{5}{|c|}{$\begin{array}{l}\text { Revised growth rate } \\
\text { (percent) }\end{array}$} & \multicolumn{5}{|c|}{$\begin{array}{l}\text { Difference between growth rates: } \\
\text { revised less earlier } \\
\text { (percentage points) }\end{array}$} \\
\hline & 1993 & 1994 & 1995 & 1996 & 1997 & 1993 & 1994 & 1995 & 1996 & $1997^{1}$ \\
\hline Total index . & 3.3 & 6.5 & 3.3 & 4.2 & 5.8 & .4 & .8 & 1.5 & .3 & .2 \\
\hline Products, total & 2.4 & 4.6 & 1.8 & 3.9 & 4.6 & .5 & .3 & .8 & .1 & .0 \\
\hline Final products . & 2.3 & 4.7 & 2.2 & 4.0 & 5.0 & .3 & .4 & .9 & -.1 & -.4 \\
\hline Consumer goods & 1.9 & 4.4 & 1.7 & 2.4 & 2.8 & -.3 & .5 & .9 & -.1 & .2 \\
\hline Durable ....... & 9.5 & 6.8 & .6 & 3.4 & 6.2 & -.8 & .3 & -.4 & 1.0 & -.4 \\
\hline Automotive products & 10.6 & 6.0 & -2.1 & 1.6 & 9.0 & -1.0 & .3 & -1.2 & .7 & -.1 \\
\hline Autos and trucks .. & 15.9 & 6.2 & -4.2 & 1.6 & 11.1 & -1.6 & .6 & -1.7 & 1.1 & -.2 \\
\hline Autos ......... & 14.4 & 6.6 & -6.9 & -3.8 & 3.7 & -2.3 & 1.7 & -2.0 & .0 & -.3 \\
\hline Trucks . & 17.1 & 4.4 & 1.6 & 8.0 & 15.8 & -.2 & -.9 & -1.4 & .7 & -.4 \\
\hline Auto parts and allied goods & 2.1 & 5.6 & 1.8 & 1.3 & 5.8 & -.1 & -.2 & .1 & .0 & .1 \\
\hline Other durable goods .......... & 8.8 & 7.4 & 2.7 & 4.8 & 3.9 & -.7 & .2 & .3 & 1.4 & -.7 \\
\hline Appliances and electronics & 18.3 & 13.4 & 8.8 & 8.0 & 6.8 & -1.4 & -.9 & -5.0 & -2.6 & -3.2 \\
\hline Appliances and air conditioning & 14.0 & 3.3 & 2.1 & 1.8 & -1.2 & 1.0 & -.5 & -2.7 & .3 & -4.4 \\
\hline Home electronics ............. & 22.5 & 25.3 & 15.4 & 15.3 & 17.2 & -4.0 & -.5 & -6.7 & -3.3 & 2.1 \\
\hline Carpeting and furniture .. & 3.4 & 5.5 & -1.4 & 5.4 & 3.6 & -.8 & .0 & 1.2 & 5.0 & 1.1 \\
\hline Miscellaneous $\ldots \ldots \ldots \ldots$ & 5.8 & 4.3 & 1.0 & 2.5 & 2.7 & -.1 & 1.1 & 4.0 & 3.1 & 1.0 \\
\hline Nondurable .. & .0 & 3.7 & 2.0 & 2.1 & 1.9 & -.2 & .5 & 1.3 & -.5 & .4 \\
\hline Nonenergy . & -.6 & 5.1 & 1.3 & 2.0 & 2.1 & -.2 & .6 & 1.6 & -.6 & 6 \\
\hline Foods and tobacco & -.9 & 6.8 & .4 & 1.9 & 1.6 & .0 & .5 & .9 & -.4 & .0 \\
\hline Clothing ........... & 1.7 & 4.3 & -5.4 & -4.1 & -1.1 & -.5 & 1.2 & 2.5 & -1.4 & -.4 \\
\hline Chemical products . & -2.0 & 5.2 & 5.2 & 4.6 & 3.8 & -.4 & -.2 & 1.5 & -.7 & 2.2 \\
\hline Paper products .......... & 1.1 & -.4 & 3.7 & 2.4 & 3.0 & -.2 & 1.9 & 3.6 & -.4 & .6 \\
\hline Energy products $\ldots \ldots \ldots \ldots$ & 3.3 & -4.1 & 6.4 & 2.8 & 1.2 & -.1 & -.1 & -.3 & .3 & -.5 \\
\hline Fuels ........... & 2.4 & -2.3 & 1.3 & 3.3 & 2.4 & .0 & .0 & .0 & .1 & -.8 \\
\hline Utilities ..... & 3.7 & -5.0 & 8.7 & 2.6 & .6 & -.2 & -.2 & -.3 & .4 & -.6 \\
\hline Equipment, total & 2.9 & 5.1 & 3.1 & 6.7 & 8.7 & 1.4 & .2 & .7 & .0 & -1.3 \\
\hline Business equipment & 4.1 & 8.6 & 5.4 & 8.2 & 10.5 & .7 & .5 & .8 & .3 & -1.0 \\
\hline Information processing and related & 3.8 & 13.5 & 13.0 & 11.8 & 12.4 & 1.8 & 2.0 & .8 & 1.1 & -2.5 \\
\hline Computer and office ............. & 15.7 & 29.8 & 43.0 & 37.4 & 32.5 & -.1 & -.5 & .2 & -1.5 & .1 \\
\hline Industrial $\ldots \ldots \ldots \ldots \ldots$ & 6.7 & 9.8 & 7.7 & .0 & 5.6 & .0 & .9 & .5 & .2 & -.8 \\
\hline Transit ... & -2.3 & -2.5 & -12.8 & 19.1 & 15.6 & -.2 & -3.7 & .6 & -2.4 & .9 \\
\hline Autos and trucks & 15.3 & 2.8 & -7.6 & .0 & 5.4 & 1.1 & -2.1 & -1.0 & 1.8 & 2.2 \\
\hline Other $\ldots \ldots \ldots \ldots$. & 9.2 & 6.1 & 1.8 & 4.8 & 9.5 & -.4 & .8 & 2.6 & 1.2 & 1.8 \\
\hline Defense and space equipment & -6.1 & -7.6 & -8.6 & -1.5 & -2.0 & .4 & .5 & -.4 & -.3 & -1.2 \\
\hline Oil and gas well drilling ...... & 24.0 & -7.0 & 2.0 & 7.0 & 9.0 & 21.8 & -5.8 & 6.3 & -7.0 & -11.2 \\
\hline Manufactured homes ..... & 7.5 & 7.6 & 6.6 & -.9 & .1 & .1 & -5.4 & -8.2 & -1.3 & -3.3 \\
\hline Intermediate products . & 2.9 & 4.4 & .6 & 3.7 & 3.4 & 1.1 & .0 & .5 & .7 & 1.0 \\
\hline Construction supplies & 5.9 & 7.2 & -.5 & 5.8 & 2.0 & .1 & .6 & .3 & .1 & -.6 \\
\hline Business supplies...$\ldots$ & 1.0 & 2.7 & 1.2 & 2.4 & 4.4 & 1.6 & -.3 & 6 & 1.1 & 2.0 \\
\hline Materials . & 4.8 & 9.6 & 5.4 & 4.7 & 7.6 & .1 & 1.7 & 2.6 & .7 & .4 \\
\hline Durable. & 8.2 & 13.9 & 10.4 & 6.7 & 11.6 & .0 & 3.0 & 4.7 & 1.2 & .7 \\
\hline Consumer parts & 16.0 & 10.1 & 2.3 & .1 & 7.2 & -.3 & 2.2 & 3.1 & -.8 & -1.0 \\
\hline Equipment parts. & 6.8 & 22.7 & 25.8 & 14.9 & 21.7 & .3 & 6.6 & 9.2 & 3.7 & 2.2 \\
\hline Other ................. & 5.9 & 9.0 & 2.1 & 3.0 & 5.2 & -.2 & .6 & 1.8 & .3 & .7 \\
\hline Basic metals & 5.1 & 7.1 & 1.4 & 2.6 & 5.6 & .2 & .6 & .8 & -.1 & 1.0 \\
\hline Nondurable ....... & 2.4 & 6.2 & -2.4 & 3.7 & 3.1 & .7 & .3 & -.1 & .9 & .3 \\
\hline Textile ........ & 4.5 & 9.1 & -7.3 & .9 & 4.0 & .2 & .5 & -.4 & -.2 & -.1 \\
\hline Paper .... & 5.5 & 5.2 & -3.9 & 2.9 & 5.1 & .1 & -.5 & -1.0 & .4 & -.9 \\
\hline Chemical & -.3 & 6.1 & -.2 & 6.1 & 1.8 & 1.5 & .6 & -.1 & 1.6 & 1.2 \\
\hline Other $\ldots \ldots \ldots$. & 3.9 & 5.8 & -2.7 & .6 & 3.7 & -.1 & .3 & 1.1 & .5 & -1.2 \\
\hline Energy $\ldots .$. & -.6 & 2.0 & .8 & .4 & 1.7 & .0 & -.1 & -.1 & -.6 & .3 \\
\hline Primary & -2.7 & 3.4 & .6 & -1.0 & .6 & .0 & .0 & -.3 & -.9 & .1 \\
\hline Converted fuel ............. & 3.3 & -.2 & 1.2 & 3.0 & 3.7 & .0 & -.2 & .2 & .2 & .5 \\
\hline \multicolumn{11}{|l|}{ Special aggregates } \\
\hline \multicolumn{11}{|l|}{ Total excluding: } \\
\hline Autos and trucks & 3.0 & 6.6 & 3.6 & 4.3 & 5.7 & .4 & .9 & 1.6 & .3 & .2 \\
\hline Motor vehicles and parts & 2.6 & 6.5 & 3.6 & 4.5 & 5.5 & .4 & .8 & 1.5 & .4 & .1 \\
\hline Computers .............. & 3.1 & 6.2 & 2.7 & 3.7 & 5.4 & .4 & .9 & 1.6 & .6 & .4 \\
\hline Computers and semiconductors . & 2.7 & 4.8 & .9 & 2.9 & 4.1 & .4 & .5 & 1.0 & .3 & .3 \\
\hline \multicolumn{11}{|l|}{ Consumer goods excluding: } \\
\hline Autos and trucks $\ldots \ldots \ldots$ & 1.1 & 4.3 & 2.1 & 2.4 & 2.3 & -.2 & .5 & 1.1 & -.2 & .2 \\
\hline Energy $\ldots \ldots \ldots \ldots \ldots$ & 1.7 & 5.5 & 1.1 & 2.3 & 3.0 & -.3 & .6 & 1.1 & -.2 & .3 \\
\hline \multicolumn{11}{|l|}{ Business equipment excluding: } \\
\hline Autos and trucks $\ldots \ldots \ldots \ldots$ & 3.0 & 9.2 & 6.9 & 9.2 & 11.0 & .6 & .8 & 1.1 & .3 & -1.2 \\
\hline Computers and office equipment . & 3.1 & 6.9 & 2.3 & 5.7 & 8.7 & .7 & .7 & 1.2 & 1.3 & .1 \\
\hline Materials excluding energy & 6.5 & 11.7 & 6.6 & 5.8 & 9.2 & .2 & 2.2 & 3.2 & 1.1 & 6 \\
\hline
\end{tabular}

Note. Growth rates are calculated as the percentage change in the seasonally 1. Through the third quarter of 1997. adjusted index from the fourth quarter of the previous year to the fourth quarter of the year specified. 
A.4. Revised growth rates of industrial production, by industry group, 1993-97

\begin{tabular}{|c|c|c|c|c|c|c|c|c|c|c|c|}
\hline \multirow[t]{2}{*}{ Series } & \multirow{2}{*}{$\begin{array}{l}\text { SIC } \\
\text { code }^{1}\end{array}$} & \multicolumn{5}{|c|}{$\begin{array}{l}\text { Revised growth rate } \\
\text { (percent) }\end{array}$} & \multicolumn{5}{|c|}{$\begin{array}{l}\text { Difference between growth rates: } \\
\text { revised less earlier } \\
\text { (percentage points) }\end{array}$} \\
\hline & & 1993 & 1994 & 1995 & 1996 & 1997 & 1993 & 1994 & 1995 & 1996 & $1997^{2}$ \\
\hline Total index & $\ldots$ & 3.3 & 6.5 & 3.3 & 4.2 & 5.8 & .4 & .8 & 1.5 & .3 & .2 \\
\hline Manufacturing . & $\ldots$ & 3.6 & 7.6 & 3.3 & 4.7 & 6.4 & .3 & 1.0 & 1.7 & .5 & .2 \\
\hline $\begin{array}{l}\text { Primary processing ... } \\
\text { Advanced processing }\end{array}$ & $\ldots$ & $\begin{array}{l}4.2 \\
3.3\end{array}$ & $\begin{array}{l}6.6 \\
8.0\end{array}$ & $\begin{array}{l}-.4 \\
5.1\end{array}$ & $\begin{array}{l}3.5 \\
5.2\end{array}$ & $\begin{array}{l}3.8 \\
7.6\end{array}$ & .2 & $\begin{array}{r}.4 \\
1.3\end{array}$ & $\begin{array}{r}.4 \\
2.3\end{array}$ & $\begin{array}{l}.6 \\
.5\end{array}$ & $\begin{array}{l}.1 \\
.2\end{array}$ \\
\hline $\begin{array}{c}\text { Durable manufacturing } \ldots \ldots \ldots \\
\text { Lumber and products } \ldots \ldots \ldots \ldots \\
\text { Furniture and fixtures } \ldots \ldots \ldots \\
\text { Stone, clay, and glass products }\end{array}$ & $\begin{array}{l}24 \\
25 \\
32\end{array}$ & $\begin{array}{l}5.9 \\
2.0 \\
3.1 \\
4.0\end{array}$ & $\begin{array}{l}9.9 \\
5.0 \\
5.3 \\
5.6\end{array}$ & $\begin{array}{r}6.2 \\
1.2 \\
.4 \\
1.5\end{array}$ & $\begin{array}{l}6.5 \\
2.8 \\
7.3 \\
3.8\end{array}$ & $\begin{array}{l}9.6 \\
1.6 \\
3.7 \\
5.3\end{array}$ & $\begin{array}{l}.1 \\
-.3 \\
-.3 \\
-.2\end{array}$ & $\begin{array}{r}1.7 \\
.9 \\
1.5 \\
.9\end{array}$ & $\begin{array}{l}2.5 \\
1.2 \\
2.2 \\
2.0\end{array}$ & $\begin{array}{r}.8 \\
.1 \\
4.8 \\
1.9\end{array}$ & $\begin{array}{r}.0 \\
-.5 \\
1.6 \\
2.0\end{array}$ \\
\hline $\begin{array}{l}\text { Primary metals } \\
\text { Iron and steel } \ldots \ldots \ldots \ldots \ldots \ldots \ldots \\
\text { Raw steel } \ldots \ldots \ldots \ldots \ldots \ldots \ldots \ldots \\
\text { Nonferrous metals } \ldots \ldots \ldots \ldots \ldots \ldots \ldots \\
\text { Fabricated metal products } \ldots \ldots \ldots \ldots \\
\text { Industrial machinery and equipment } \\
\text { Computer and office equipment } \\
\text { Electrical machinery } \ldots \ldots \ldots \ldots \ldots \ldots\end{array}$ & $\begin{array}{r}33 \\
331,2 \\
331 \mathrm{pt} \\
333-6,9 \\
34 \\
35 \\
357 \\
36\end{array}$ & $\begin{array}{r}7.4 \\
8.9 \\
5.7 \\
5.4 \\
4.4 \\
11.6 \\
18.9 \\
10.4\end{array}$ & $\begin{array}{r}8.9 \\
7.8 \\
6.2 \\
10.4 \\
9.0 \\
15.3 \\
30.5 \\
27.2\end{array}$ & $\begin{array}{r}-.4 \\
-.9 \\
.7 \\
.2 \\
1.2 \\
12.4 \\
37.8 \\
25.7\end{array}$ & $\begin{array}{r}3.5 \\
2.2 \\
-1.7 \\
4.9 \\
3.2 \\
7.6 \\
36.5 \\
12.6\end{array}$ & $\begin{array}{r}6.2 \\
6.7 \\
8.0 \\
5.5 \\
4.0 \\
11.3 \\
34.4 \\
18.7\end{array}$ & $\begin{array}{r}.2 \\
-.1 \\
.1 \\
.5 \\
-.1 \\
-.5 \\
-1.3 \\
1.8\end{array}$ & $\begin{array}{r}.5 \\
.8 \\
.1 \\
.1 \\
.5 \\
.6 \\
. .7 \\
-.7 \\
8.7\end{array}$ & $\begin{array}{r}.5 \\
.2 \\
.1 \\
.9 \\
.3 \\
.8 \\
-2.9 \\
9.8\end{array}$ & $\begin{array}{r}-.2 \\
-.2 \\
.0 \\
-.2 \\
.5 \\
-2.3 \\
-1.0 \\
5.4\end{array}$ & $\begin{array}{r}.3 \\
.6 \\
-.3 \\
.0 \\
-.5 \\
-2.9 \\
2.3 \\
2.4\end{array}$ \\
\hline $\begin{array}{l}\text { Semiconductors and related } \\
\text { components } \ldots . . . \ldots . . .\end{array}$ & $3672-9$ & 16.5 & 55.0 & 59.3 & 25.5 & 40.2 & .0 & 17.7 & 22.9 & 9.5 & 8.8 \\
\hline $\begin{array}{r}\text { Transportation equipment } \ldots . . . \\
\text { Motor vehicles and parts } \ldots . . \\
\text { Autos and light trucks } \ldots . \\
\text { Aerospace and miscellaneous }\end{array}$ & $\begin{array}{r}37 \\
371 \\
371 \mathrm{pt}\end{array}$ & $\begin{array}{r}4.5 \\
17.5 \\
13.2\end{array}$ & $\begin{array}{l}1.3 \\
7.8 \\
5.1\end{array}$ & $\begin{array}{l}-5.3 \\
-1.6 \\
-4.5\end{array}$ & $\begin{array}{r}5.5 \\
-1.4 \\
1.0\end{array}$ & $\begin{array}{r}11.6 \\
10.9 \\
9.6\end{array}$ & $\begin{array}{l}-.3 \\
-.5 \\
-.4\end{array}$ & $\begin{array}{r}.1 \\
1.0 \\
-.6\end{array}$ & $\begin{array}{r}.9 \\
1.4 \\
-1.3\end{array}$ & $\begin{array}{r}-1.0 \\
.2 \\
1.4\end{array}$ & $\begin{array}{r}.4 \\
1.2 \\
-.4\end{array}$ \\
\hline $\begin{array}{l}\text { transportation equipment } \\
\text { Instruments ...................... } \\
\text { Miscellaneous manufactures . . }\end{array}$ & $\begin{array}{r}372-6,9 \\
38 \\
39\end{array}$ & $\begin{array}{r}-9.0 \\
-1.8 \\
5.7\end{array}$ & $\begin{array}{r}-7.1 \\
.7 \\
3.9\end{array}$ & $\begin{array}{r}-10.8 \\
1.9 \\
3.3\end{array}$ & $\begin{array}{r}17.0 \\
4.2 \\
5.2\end{array}$ & $\begin{array}{r}12.7 \\
3.9 \\
4.1\end{array}$ & $\begin{array}{r}-.1 \\
-.1 \\
.2\end{array}$ & $\begin{array}{r}-1.1 \\
-.5 \\
1.3\end{array}$ & $\begin{array}{l}-.3 \\
1.4 \\
2.4\end{array}$ & $\begin{array}{r}-1.9 \\
1.5 \\
2.0\end{array}$ & $\begin{array}{l}-.5 \\
-.2 \\
1.5\end{array}$ \\
\hline 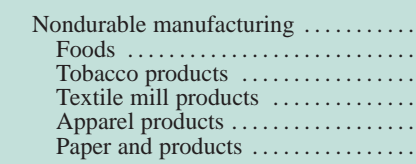 & $\begin{array}{l}20 \\
21 \\
22 \\
23 \\
26\end{array}$ & $\begin{array}{r}1.0 \\
1.6 \\
-16.3 \\
4.8 \\
1.7 \\
6.6\end{array}$ & $\begin{array}{r}4.9 \\
2.4 \\
43.5 \\
6.0 \\
6.6 \\
4.6\end{array}$ & $\begin{array}{r}-.1 \\
1.6 \\
-5.2 \\
-5.1 \\
-4.5 \\
-2.8\end{array}$ & $\begin{array}{r}2.5 \\
1.7 \\
2.4 \\
.1 \\
-3.4 \\
2.3\end{array}$ & $\begin{array}{r}2.7 \\
2.0 \\
.6 \\
5.1 \\
-1.6 \\
4.9\end{array}$ & $\begin{array}{r}.4 \\
.0 \\
.0 \\
-.2 \\
-.5 \\
.0\end{array}$ & $\begin{array}{r}.2 \\
.4 \\
3.1 \\
.0 \\
1.4 \\
-.1\end{array}$ & $\begin{array}{r}.8 \\
.8 \\
3.6 \\
.4 \\
3.1 \\
-.3\end{array}$ & $\begin{array}{r}.2 \\
-.4 \\
-.2 \\
-.4 \\
-.7 \\
.6\end{array}$ & $\begin{array}{r}.5 \\
.0 \\
1.0 \\
.3 \\
-.4 \\
-.3\end{array}$ \\
\hline $\begin{array}{l}\text { Printing and publishing } \ldots . . . \\
\text { Chemicals and products .... } \\
\text { Petroleum products ....... } \\
\text { Rubber and plastic products } \\
\text { Leather and products ....... }\end{array}$ & $\begin{array}{l}27 \\
28 \\
29 \\
30 \\
31\end{array}$ & $\begin{array}{r}-.5 \\
-1.0 \\
2.6 \\
6.7 \\
-3.3\end{array}$ & $\begin{array}{r}1.2 \\
4.7 \\
-1.0 \\
9.6 \\
-8.9\end{array}$ & $\begin{array}{r}.0 \\
2.1 \\
.5 \\
.0 \\
-11.0\end{array}$ & $\begin{array}{r}1.6 \\
5.4 \\
3.3 \\
3.4 \\
-4.0\end{array}$ & $\begin{array}{r}3.9 \\
2.0 \\
2.6 \\
4.1 \\
-7.8\end{array}$ & $\begin{array}{r}2.1 \\
.4 \\
-.2 \\
.2 \\
.6\end{array}$ & $\begin{array}{r}.0 \\
.1 \\
.0 \\
.1 \\
-.6\end{array}$ & $\begin{array}{r}1.4 \\
.5 \\
.1 \\
.5 \\
-2.1\end{array}$ & $\begin{array}{r}1.2 \\
.3 \\
-.1 \\
.9 \\
.7\end{array}$ & $\begin{array}{l}2.0 \\
1.1 \\
-.1 \\
-.7 \\
-.8\end{array}$ \\
\hline $\begin{array}{l}\text { Mining } \ldots \ldots \ldots \ldots \ldots \ldots \ldots \ldots \\
\quad \text { Metal mining } \ldots \ldots \ldots \ldots \ldots \ldots \ldots \ldots \ldots \ldots \\
\text { Coal mining } \ldots \ldots \ldots \ldots \ldots \ldots \ldots \ldots \ldots \\
\text { Oil and gas extraction } \ldots \ldots \ldots \ldots \ldots \ldots \\
\text { Stone and earth minerals } \ldots \ldots \ldots \ldots \ldots\end{array}$ & $\begin{array}{l}10 \\
12 \\
13 \\
14\end{array}$ & $\begin{array}{r}1.7 \\
2.5 \\
-3.1 \\
2.2 \\
5.7\end{array}$ & $\begin{array}{r}.9 \\
-3.1 \\
9.2 \\
-1.2 \\
6.9\end{array}$ & $\begin{array}{r}-.8 \\
4.5 \\
-.1 \\
-1.5 \\
-1.2\end{array}$ & $\begin{array}{r}1.7 \\
3.3 \\
2.5 \\
.9 \\
5.4\end{array}$ & $\begin{array}{r}2.3 \\
5.2 \\
4.2 \\
2.0 \\
.4\end{array}$ & $\begin{array}{r}2.0 \\
.3 \\
.1 \\
2.8 \\
.1\end{array}$ & $\begin{array}{r}-.7 \\
-.1 \\
.3 \\
-1.0 \\
-.1\end{array}$ & $\begin{array}{r}.5 \\
-.3 \\
.1 \\
.9 \\
-1.3\end{array}$ & $\begin{array}{r}-1.7 \\
1.6 \\
-1.6 \\
-2.1 \\
-1.5\end{array}$ & $\begin{array}{r}-.1 \\
.3 \\
-.4 \\
-.3 \\
.0\end{array}$ \\
\hline $\begin{array}{l}\text { Utilities ... } \\
\text { Electric } \\
\text { Gas .... }\end{array}$ & $\begin{array}{l}491,493 \mathrm{pt} \\
492,493 \mathrm{pt}\end{array}$ & $\begin{array}{l}2.0 \\
1.1 \\
5.2\end{array}$ & $\begin{array}{r}-.3 \\
1.7 \\
-7.7\end{array}$ & $\begin{array}{r}6.4 \\
5.3 \\
10.8\end{array}$ & $\begin{array}{l}1.5 \\
1.0 \\
3.1\end{array}$ & $\begin{array}{l}2.3 \\
2.6 \\
1.1\end{array}$ & $\begin{array}{r}.0 \\
.1 \\
-.2\end{array}$ & $\begin{array}{l}-.2 \\
-.2 \\
-.5\end{array}$ & $\begin{array}{r}-.1 \\
.0 \\
-.1\end{array}$ & $\begin{array}{l}.0 \\
.1 \\
.0\end{array}$ & $\begin{array}{r}.1 \\
-.5 \\
1.9\end{array}$ \\
\hline 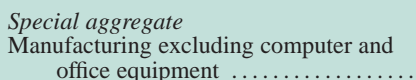 & & 3.3 & 7.1 & 2.6 & 4.0 & 5.9 & .3 & 1.1 & 1.9 & .8 & .5 \\
\hline
\end{tabular}

NotE. Growth rates are calculated as the percentage change in the seasonally adjusted index from the fourth quarter of the previous year to the fourth quarter of the year specified.

Primary-processing manufacturing includes textile mill products; paper and products; industrial chemicals, synthetic materials, and fertilizers; petroleum products; rubber and plastics products; lumber and products; primary metals; fabricated metals; and stone, clay, and glass products. Advanced-processing manufacturing includes foods, tobacco products, apparel products, printing and publishing, chemical products and other agricultural chemicals, leather and

products, furniture and fixtures, industrial and commercial machinery and computer equipment, electrical machinery, transportation equipment, instruments, and miscellaneous manufactures.

1. Standard Industrial Classification; see Executive Office of the President, Office of Management and Budget, Standard Industrial Classification Manual, 1987 (U.S. Government Printing Office, 1987).

2. Through the third quarter of 1997.

pt Part of classification. 
A.5. Revised growth rates of capacity, by industry group, 1993-97

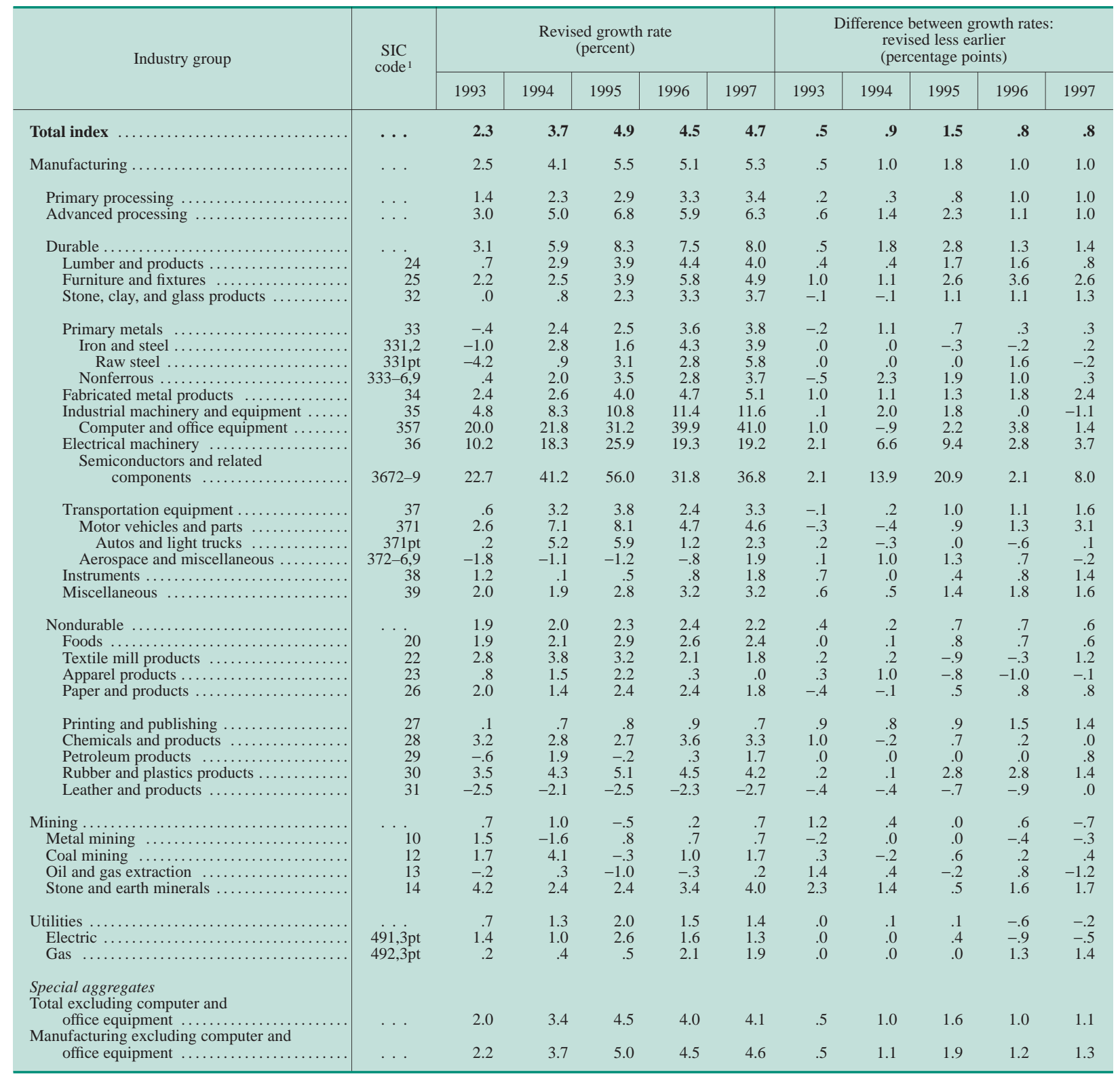

Note. See note to table A.4.

pt Part of classification.

1. Standard Industrial Classification; see table A.4, note 1. 
A.6. Revised and earlier capacity utilization rates, by industry group, 1967-97

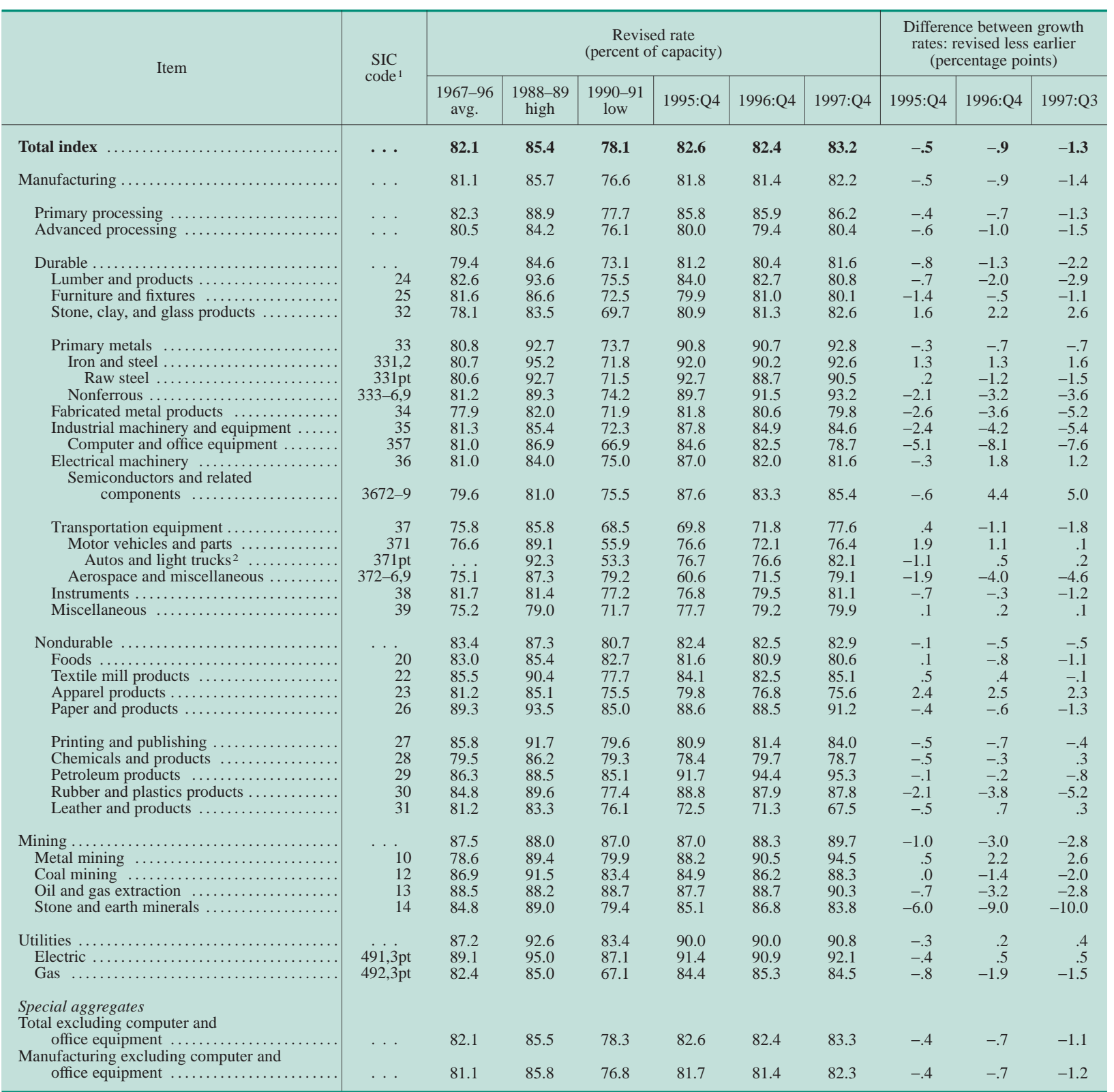

NoTE. The "high" column refers to periods in which utilization generally peaked; the "low" column refers to recession years in which utilization gener-

1. Standard Industrial Classification; see table A.4, note 1 . ally bottomed out. The monthly highs and lows are specific to each series, and 2. Series begins in 1977. all did not occur in the same month. 